Abandoning the Black Hero 



\section{ABANDONING THE BLACK HERO}

Sympathy and Privacy in the Postwar African American White-Life Novel

JOHN C. CHARLES

Rutgers University Press

NEW BRUNSWICK, NEW JERSEY, AND LONDON 
Charles, John C., 1968-

Abandoning the Black hero : sympathy and privacy in the postwar African American white-life novel / John C. Charles.

p. cm.

Includes bibliographical references and index.

ISBN 978-0-8135-5433-4 (hardcover : alk. paper)

ISBN 978-0-8135-5432-7 (pbk. : alk. paper)

ISBN 978-0-8135-5434-1 (e-book)

1. American fiction-African American authors-History and criticism. 2. American fiction-2oth century-History and criticism. 3. African Americans-Intellectual life2oth century. 4. Whites in literature. 5. Race in literature. I. Title.

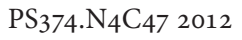

$813^{\prime} .5409896073-\mathrm{dc} 23$

A British Cataloging-in-Publication record for this book is available from the British Library.

Copyright $\odot 2013$ by John C. Charles

All rights reserved

No part of this book may be reproduced or utilized in any form or by any means, electronic or mechanical, or by any information storage and retrieval system, without written permission from the publisher. Please contact Rutgers University Press, 106 Somerset Street, New Brunswick, NJ 08901. The only exception to this prohibition is "fair use" as defined by U.S. copyright law.

Visit our website: http://rutgerspress.rutgers.edu

Manufactured in the United States of America

THE

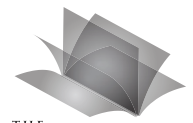

A M E R I C A N

LITERATURES

I N I T I A T I V E
A book in the American Literatures Initiative (ALI), a collaborative publishing project of NYU Press, Fordham University Press, Rutgers University Press, Temple University Press, and the University of Virginia Press. The Initiative is supported by The Andrew W. Mellon Foundation. For more information, please visit www.americanliteratures.org. 
To my three mothers:

Patricia Ann Williamson Ghannam,

Barbara Lee Williamson, and

Constance Marion Alger 
